\title{
Meningkatkan Kemampuan Menjelaskan Potensi Indonesia Menjadi Negara Maju Melalui Metode Menjodohkan Pada Siswa SMP Negeri 1 Siak Hulu
}

\author{
ASNETY \\ Dinas Pendidikan Kabupaten Kampar \\ SMP Negeri 1 Siak Hulu \\ E-mail : asnety_smp1a@gmail.com
}

\begin{abstract}
Social studies lessons especially in discussing various conditions of the future of Indonesia, where the nation is developing and when viewed from the lessons given students are expected to be able to provide explanations that were previously able to understand the condition of Indonesia and from the initial observation the problems that arise are students' logic and understanding of conditions thus still low. This problem might be answered by applying matchmaking learning methods. Through classroom action research conducted on class IX students of 1 Siak Hulu Middle School and the data were analyzed using qualitative techniques, the results of the study showed that the application of matchmaking methods could improve students' ability to explain the potential of Indonesia to become a developed country. Changes in student attitudes and behavior are also getting better and make students more enthusiastic in learning.
\end{abstract}

Keywords: Matching Method, Student Ability

Rendahnya capaian siswa mempelajari topik usaha potensi Indonesia menjadi negara maju. Yang mana tujuan pembelajarannya adalah setelah selesai melaksanakan kegiatan pembelajaran siswa dapat menjelaskan potensi Indonesia menjadi negara maju.

Pada mata pelajaran IPS (Ilmu Pengetahuan Sosial) merupakan salah satu mata pelajaran yang diberikan mulai dari SD/MI/SDLB sampai SMP/MTs/SMPLB. IPS mengkaji seperangkat peristiwa, fakta, konsep, dan generalisasi yang berkaitan dengan isu sosial. Pada jenjang SMP mata pelajaran IPS memuat materi Geografi, Sejarah, Sosiologi, dan Ekonomi. Melalui mata pelajaran IPS, peserta didik diarahkan untuk dapat menjadi warga negara Indonesia yang demokratis, dan bertanggung jawab serta warga dunia yang cinta damai.

Di masa yang akan datang peserta didik akan menghadapi tantangan berat karena kehidupan masyarakat global selalu mengalami perubahan setiap saat. Oleh karena itu mata pelajaran IPS dirancang untuk mengembangkan pengetahuan, pemahaman, dan kemampuan analisis terhadap kondisi sosial masyarakat dalam memasuki kehidupan bermasyarakat yang dinamis. Mata pelajaran IPS disusun secara sistematis, komprehensif, dan terpadu dalam proses pembelajaran menuju kedewasaan dan keberhasilan dalam kehidupan di masyarakat. Dengan pendekatan tersebut diharapkan peserta didik akan memperoleh pemahaman yang lebih luas dan mendalam pada bidang ilmu yang berkaitan.

Setelah mempelajari mata pelajaran ini sebagai standar kompetensi mampu menjelaskan potensi Indonesia menjadi negara maju. Namun dari capaian prestasi belajar pada sub bahasan tersebut, siswa kurang mampu mengingat dan mendeskripsikan peristiwa-peristiwa politik dan ekonomi Indonesia pasca kedaulatan juga dapat dilihat dari capaian nilai mata pelajaran IPS yang paling rendah adalah pada sub bahasan ini. Selama ini metode pembelajaran yang digunakan dalam memberikan materi pelajaran IPS pada sub bahasan tersebut adalah melalui metode ceramah, 
permasalahan tersebut menunjukkan penggunaan metode ceramah dinilai kurang efektif dalam mencapai ketuntasan belajar siswa pada mata pelajaran IPS.

Penelitian ini mengarahkan penggunaan metode pembelajaran menjodohkan, karena diharapkan melalui metode ini siswa dapat menjelaskan potensi Indonesia menjadi negara maju.

Menjodohkan atau model pembelajaran kooperatif tipe Matching Math merupakan kegiatan pembelajaran yang melibatkan secara maksimal seluruh kemampuan siswa dalam berdiskusi dalam mencocokkan kartu, antara kartu yang berisikan materi dengan kartu yang berisikan tentang penjelasan tentang materi pada kartu yang selanjutnya, metode ini menggunakan tiga kartu dan kartu yang satu lagi berisikan tentang soal-soal pengembangan tentang materi.

Kegiatan belajar mengajar terdapat dua unsur yang amat penting adalah metode mengajar dan metode pengajaran. Kedua aspek ini sangat berkaitan. Pemilihan salah satu media mengajar tentu akan mempengaruhi jenis media pembelajaran yang sesuai, meskipun masih ada berbagai aspek lain yang harus diperhatikan.

Metode pembelajaran menjodohkan menurut Indah Wati (2013) tes menjodohkan pada prinsipnya dapat mengevaluasi pengetahuan tentang fakta yang memiliki makna spesifik. Agar dapat digunakan sebagai materi termis atau kolom respon, fakta harus sederhana dan jelas. Matching test dapat kita ganti dengan istila memperbandingkan, mencocokkan, memasangkan, atau menjodohkan. Maching test terdiri atas satu seri pertayaan, dan satu seri jawaban. Masing-masing pertanyaan mempunyai jawaban yang tercantum dalam seri jawaban. Tuga murid ialah mencari dan mendapatkan jawabannya, sehingga sesuai dan cocok dengan pertanyaannya.

Bentuk ini meminta peserta tes untuk menjodohkan, atau memasangkan kata-kata yang terdapat dalam satu kelompok dengan kata-kata yang terdapat pada kelompok lain. Menjodohkan dua hal dapat berupa:antara peristiwa dengan orang, antara peristiwa dengan hari, peristiiwa dengan tempat, istilah dengan definisi, hukum dengan ilustrasi, peraturan dengan contoh, alat dengan penggunaanya dan sebagainya. Penggunaan tes ini dapat mengurangi keberhasilan para peserta tes hanya dengan cara menerka, berguna untuk mengidentifikasi sejumlah tempat atau bagian pada peta, grafik dan diagram, namun terdapat beberapa kekurangan antara lain: hanya mengukur aspek kognitif tingkat rendah (pengetahuan, pemahaman, dan sedikit aplikasinya), memerlukan waktu yang cukup banyak untuk mengerjakannya.

Menurut Muhammad Karwapi (2012) Dalam menulis soal bentuk menjodohkan, penulis soal harus mengetahui konsep dasar bentuk menjodohkan. Bentuk ini wujudnya terdiri dari dua kelompok atau kolom. Tugas siswa adalah mencari pasangan yang tepat dalam dua kelompok itu. Misalnya siswa harus dapat mencocokkan antara kejadian dan tanggal kejadian yang tepat, kejadian dengan orang, kejadian dengan tempat, istilah dengan definisi, perkataan asing/istilah asing dengan istilah bahasa Indonesia yang baku, peraturan-peraturan dengan contoh, alat-alat dengan penggunaannya dan lain-lain. Biasanya bentuk menjodohkan hanya terbatas untuk mengukur kemampuan ingatan. Bentuk soal ini juga dapat dipergunakan untuk menentukan nama dari tempat-tempat atau bagian-bagian yang telah diberi nomor pada peta, diagram dan sebagainya.

Adapun kaidah penulisan soal bentuk menjodohkan adalah :

Materi

1. Soal harus sesuai dengan indikator.

2. Materi yang diukur sesuai dengan tuntutan bentuk menjodohkan.

3. Gunakan materi-materi yang homogen untuk setiap kelompok, baik kelompok soal (pokok soal) maupun pilihan jawabannya.

Konstruksi 
1. Pertanyaan dan pilihan jawaban harus disusun dengan homogen, paralel/sejajar.

2. Soal disusun sebelah kiri dengan bernomor, pilihan jawaban disusun di sebelah kanan dengan nomor urut dengan huruf.

3. Pertanyaan dan pilihan jawaban hendaknya disusun secara sistematis. Jika daftar terdiri dari tanggal disusun secara kronologis, sedangkan pertanyaan dalam pilihan jawaban dapat disusun menurut abjad.

4. Pertanyaan dan pilihan jawaban ditulis dalam halaman yang sama. Bila tidak demikian dapat membingungkan siswa dan dapat menyita waktu lama yang dipergunakan untuk membolak balik halaman saja.

5. Panjang soal ini dibatasi jumlah tidak lebih dari 10 - 15 butir soal. Daftardaftar yang panjang cenderung akan menjadi terlalu heterogen dan dengan demikian memungkinkan adanya petunjuk-petunjuk bagi siswa yang pandai, lagi pula soal bentuk ini bila soalnya terlalu panjang/banyak akan membuang waktu yang terlalu banyak.

6. Jumlah pilihan jawaban disusun lebih banyak daripada soalnya. Hal ini dimaksudkan agar siswa dapat memikirkan jawaban dengan tepat.

7. Pokok soal dan pilihan jawaban disusun dengan pertanyaan yang pendek.

8. Petunjuk mengerjakan soal harus jelas.

Menurut Muh. Ali Nasution (2004) metode menjodohkan atau mencari pasangan (make - match) digunakan untuk memudahkan mengingat dengan langkahlangkah sebagai berikut:

1. Guru menyiapkan beberapa kartu yang berisi konsep atau topik yang cocok untuk sesi review, sebaliknya satu bagian kartu soal dan bagian lainnya kartu jawaban.
2. Setiap siswa mendadak satu buah kartu soal

3. Tiap siswa memikirkan jawaban soal dari kartu yang dipegang.

4. Setiap siswa mencari pasangan yang mempunyai kartu yang cocok dengan kartunya (soal jawaban).

5. Setiap siswa yang dapat kecocokan kartunya sebelum batas waktu yang disediakan habis diberi poin.

6. Setelah satu babak, kartu dikocok lagi agar tiap siswa mendapatkan kartu yang berbeda dari sebelumnya.

7. Demikian seterusnya.

8. Kesimpulan dan repleksi

9. Penutup.

\section{METODE}

Penelitian ini menggunakan penelitian tindakan karena penelitian tindakan kelas adalah merupakan penelitian yang lebih sesuai dengan tugas pokok dan fungsi guru, meningkatkan kualitas pembelajaran, meningkatkan kualitas siswa, serta mencapai tujuan pembelajaran atau pendidikan.Dalam penelitian ini memakai penelitian tindakan kelas adalah bentuk kajian yang bersifat reflektif. Pada penelitian ini disamping untuk memantu permasalahan belajar yang dihadapi siswa juga membantu guru dalam upaya memperbaiki cara mengajarnya selama kegiatan belajar mengajar berlangsung.

Refleksi tindakan yang diperoleh bisa berupa (a) praktik-praktik sosial atau pendidikan yang dilakukan oleh guru, (b) pemahaman terhadap praktik-praktik tersebut dan (c) situasi yang melatarbelakangi praktik itu dilaksanakan. Penelitian tindakan kelas dilakukan secara kolaboratif, untuk kemantapan rasional dalam pelaksanaan tugas, serta memperbaiki kondisi tempat praktik pembelajaran sendiri.

Dalam penelitian ini yang menjadi subyek penelitian adalah siswa kelas IX SMP N 1 Siak Hulu Tahun Pelajaran 20172018. Jumlah siswa Kelas IX seluruhnya adalah 32 siswa. Penelitian ini dilaksanakan 
di Kelas IX SMP N 1 Siak Hulu, untuk mata pelajaran IPS.

Metode pengumpulan data pada penelitian ini adalah observasi, tes, wawancara dan catatan lapangan. Teknik analisis data yang dipergunakan adalah reduksi data, penyajian data, penarikan simpulan, serta verifikasi refleksi.

\section{HASIL}

Hasil penelitian ini terbagi menjadi tiga siklus, yang dimulai dari refleksi awal. Refleksi awal dilaksanakaan dengan melakukan pengamatan pendahuluan untuk mengetahui kondisi awal dilakukan oleh pengamat kelas, yakni rekan sejawat. Hasil refleksi awal dipergunakan untuk menetapkan dan merumuskan rencana tindakan yaitu menyusun strategi awal pembelajaran.

Berdasarkan hasil pengamatan pendahuluan ditemukan bahwa selama pembelajaran berlangsung sebagian besar siswa cenderung kurang berminat mengikuti pelajaran didepan kelas, kurang memperhatikan penjelasan guru, kurang bersemangat dan cenderung pasif, tidak aktif dalam mengemukakan pendapat atau bertanya dalam mengikuti proses pembelajaran.

Minat belajar siswa dalam pembelajaran kurang ditandai dengan banyaknya siswa selama pembelajaran berlangsung tidak ada minat untuk segera menjelaskan minat untuk bertanya juga kurang karena siswaa cenderung pasif pada waktu guru memberikan pertanyaan atau saat guru memberikan tugas.Selanjutnya dilakukan refleksi atau pemaknaan terhadap perilaku siswa tersebut. Berdasarkan hasil refleksi dapat disimpulkan bahwa siswa kurang berminat dan kurang terampil dalam menyelesaikan masalah menyajikan peristiwa-peristiwa politik dan ekonomi Indonesia pasca kedaulatan.

Kegiatan pembelajaran dapat disajikan dengan menggunakan strategi atau pendekatan dan penggunaan metode menjodohkan dan dapat mengatasi permasalahan tersebut, yaitu metode pembelajaran berdasarkan masalah. Akhirnya kegiatan pembelajaran dapat berjalan dengan wajar, motivasi belajar siswa meningkat, dan pada akhirnya pestasi belajar siswa meningkat.

Untuk lebih jelasnya hasil penelitian dapat dilihat dari gambar berikut ini:

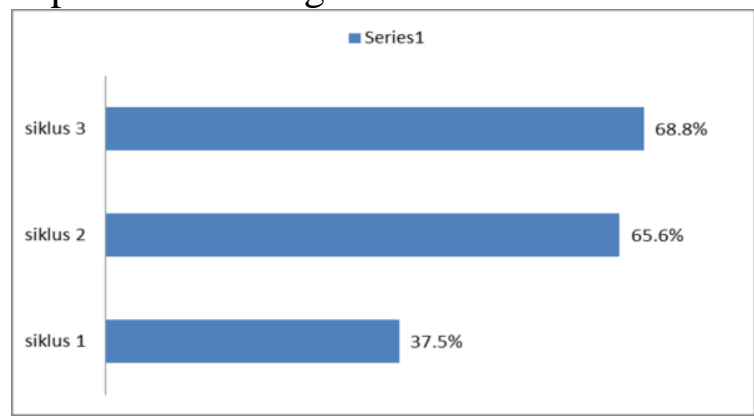

Berdasarkan pengamatan, siswa dalam pembelajaran pada siklus pertama prestasi belajar siswa rata-rata 74 dan pada siklus I yang tuntas ada (37.5\%) yang tidak tuntas ada (62.5\%).

Pada siklus ketiga guru harus lebih semangat kepada siswa untuk lebih berhasil, agar ketuntasan tercapai maksimal.Pada kegiatan mencari jawaban yang paling benar, hafalan terhadap penjelasan guru perlu lebih ditingkatkan dengan cara memberi penjelasan yang lebih mendetail sehingga jawaban dari soal lebih dapat dengan mudah dihafalkannya. Setiap siswa diberi kesempatan bertanya dan mengemukakan pendapat agar mereka lebih hafal dalam memberikan jawaban dari pertanyaan pada kartu yang diberikan. Hasil belajar siswa pada siklus kedua tampak pengamatan, siswa dalam pembelajaran pada siklus kedua prestasi belajar siswa rata-rata 80 dan pada siklus kedua yang tuntas ada $(65.6 \%)$ yang tidak tuntas ada (34.4\%).

Pada siklus ketiga siswa lebih mampu mendeskripsikan atau menghafal selama kegiatan pembelajaran siswa tampak aktif, komunikatif karena tiap siswa telah memahami dan mengerti urutannya. Hasil belajar siswa pada siklus ketiga tampak siswa dalam pembelajaran pada siklus ketiga prestasi belajar siswa rata-rata 85 dan pada siklus ketiga yang tuntas ada $(68.8 \%)$ 
yang tidak tuntas ada $(31.3 \%)$.

\section{PEMBAHASAN}

Berdasarkan hasil penelitian tindakan kelas pada kelas IX pada mata pelajaran IPS dapat disimpulkan bahwa terjadi perubahan perbaikan prestasi siswa. Melalui penerapan metode penjodohan dengan memberikan kartu pertanyaan sebagai bentuk review dari penjelasan guru di kelas dan siswa diminta untuk memikirkan jawaban dan menjodohkan dengan rekan yang memiliki kartu yang sama maka dapat dibuktikan bahwa adanya prestasi siswa dari ketuntasan 80 semakin meningkat.

Hal ini sejalan dengan pendapat Ajis (2012) penelitian ini bertujuan untuk mengetahui implementasi teknik make a match untuk meningkatkan motivasi belajar IPS pada siswa kelas IX SMP N 1 Siak Hulu. Penelitian ini merupakan Penelitian Tindakan Kelas (PTK/Classroom Action Research). Penelitian ini dilakukan secara kolaborasi dengan guru. Penelitian ini dilaksanakan dalam bentuk siklus. Setiap siklus terdiri dari empat tahap yaitu: perencanaan, pelaksanaan tindakan, pengamatan, refleksi. Pembelajaran menggunakan model make a match berbentuk kartu berpasangan (soal dan jawaban).

Juga dijelaskan oleh Suroto, dkk (2017) bahwa melalui penelitian tindakan kelas akan mampu menghasilkan solusi dari masalah siswa yang terjadi dan juga menjadikan temuan baru dalam belajar.

\section{SIMPULAN}

Berdasarkan hasil penelitian yang sebagaimana telah diuraikan di atas, maka dapat ditarik kesimpulan bahwa penerapan metode menjodohkan mampu meningkatkan kemampuan menjelaskan siswa tentang potensi Indonesia menjadi Negara maju. Perubahan sikap dan perilaku siswa juga semakin baik dan menjadikan siswa lebih bersemangat dalam belajar.

\section{DAFTAR RUJUKAN}

Ajis (2012) Implementasi Model Cooperative Learning Teknik Make A Match Untuk Meningkatkan Motivasi Belajar IPS Pada Siswa Kelas VIII A SMP $N 1$ Wedi, Klaten. S1 Thesis, Universitas Negeri Yogyakarta.

Anwar Kurnia, 2013, IPS Terpadu SMP Kelas VII, Yudistira, Jakarta.

Arikunto, Suharsimi. 2005. Dasar-Dasar Evaluasi Pendidikan. Jakarta:Bumi Aksara.

Indah Wati, 2013, Item Tes Menjodohkan

Muhammad Karwapi, 2012, Kaidah Penulisan Soal Bentuk Menjodohkan dan Bentuk Benar Salah (B-S) yang Sah dan Valid

Muh. Ali Nasution, 2004, Alternatif strategi pembelajaran pengetahuan sosial

Suroto, B., Novita, N., Pailis, E. A., Waldelmi, I., \& Fatkhurahman, F. (2017). Metode Penelitian Tindakan Solusi Bagi Masalah Sosial. Jurnal Diklat Review, 1(1), 25-28. 